\title{
THE STUDENT-AS-CONSUMER PARADOX IN ONLINE HIGHER EDUCATION
}

\author{
Joseph Rene Corbeil, The University of Texas at Brownsville, rene.corbeil@utb.edu \\ Maria Elena Corbeil, The University of Texas at Brownsville, mariaelena.corbeil@utb.edu
}

\begin{abstract}
In the business world, exceptional customer service is vital to customer satisfaction, retention, and loyalty. Until recently, colleges and universities had a monopoly on higher education in their protected territories. Today, they are facing extreme competition from online interlopers encroaching on their formerly exclusive target audiences, necessitating a shift in how they react to students' newfound power to choose how and where they obtain their education. This paper will provide: an analysis of the arguments for and against viewing students as consumers; student perceptions on what customer service should look like in online courses; and a common-sense approach to merging best practices of customer service quality to best practices in online instruction.
\end{abstract}

Keywords: E-Learning, Higher Education, Customer Service, Best Practices

\section{INTRODUCTION}

With the exponential growth of online education from both private and public institutions, prospective students are no longer limited by geography to pursue educational opportunities. Today's students are empowered by a multitude of higher education options that were not available to them as recently as 5 years ago. This is evidenced by the increase in the number of online student enrollment, as well as online courses and programs offered by higher education institutions. Recently, Allen and Seaman [1], the authors of Changing Course: Ten Years of Tracking Online Education in the United States, reported that since they started tracking the progress of online education in the United States in 2002, "the number of students taking at least one online course increased by over 570,000 to a new total of 6.7 million" [1, p. 4). Not surprisingly, the number of higher education institution administrators who reported that online education was a critical component to their institution's long-term strategy, grew from "less than one-half" in 2002, to "close to seventy percent" in 2013 [1, p. 4]. The authors added that this is "the highest it has been for this ten-year period" [1, p. 4]. Conversely, the number of higher education respondents who reported that "online education is not critical to their long-term strategy...dropped to a new low of 11.2 percent" [1, p. 4].

These numbers are not new or alarming. However, they are game changers for higher education. Colleges and universities that have traditionally relied on the local population for their recruits must adapt to a new reality where students see themselves as consumers, and as consumers, they have the ability to choose where and how they get their education. This new reality is forcing some institutions to adopt a more entrepreneurial, student-focused approach to recruitment and retention in order to remain competitive.

Yet, while exceptional customer service is the hallmark of many institutions while they are courting potential students, it often seems that the extraordinary service and care that attracts students to the institution stops at the entrance to the course, which begs the question, "should customer service be extended to every facet of higher education, including in the classroom, and especially, the online classroom?"

Consider the following actual case:

After nearly 15 years since her last college class, Joanna anxiously awaited the start of her first fully online graduate course. Her decision to return to school for a Master's degree was thoughtfully researched, and her decision to select a fully online program, despite some apprehension, was made, in part, by implicit assurances of high quality customer service, as well as convenient and flexible classes. When the first class day arrived, Joanna nervously logged in to the course not knowing what to expect.

To her disbelief, the course looked like it was not ready for the start of classes. The login screen was chaotic, with no welcome instructions. Many of the hyperlinks were broken and the course calendar still displayed the previous semester's dates. Troubled, Joanna emailed the professor to inquire if she had 
inadvertently enrolled into the wrong section of the course. Determined to finish what she started, she reviewed the available materials to get a sense of the course expectations. Within the next two days, she sent the instructor two additional emails, which went unanswered.

On the third day, the instructor posted his first message to the class, informing them of an orientation meeting on the following Saturday morning. Expecting to have her questions answered, Joanna logged in to the live session early. Instead of apologizing for not having the course ready for first day of class, the instructor berated the students for their panicky emails. The first week of class set the tone for the rest of the semester.

As horrific as this story may seem, it sadly, is not unique in online programs. While the quality of online courses is rapidly improving, there is still considerable room for improvement. Had the previous case happened in any setting other than education, the employee would have been reprimanded or terminated. While there is merit to extending some form of customer care to the online classroom, some scholars worry that such a move might interfere with the student-faculty relationship.

\section{THE STUDENT AS CONSUMER METAPHOR}

Seeing students as consumers can set the stage for strategically planning and implementing an institution-wide customer service plan, which can result in increased enrollment, persistence, and graduation rates. Conversely, it can also tax the institution, demanding significant resources, as well as commitment and time from staff and faculty. Therefore, it is not surprising that there are people in higher education who passionately argue for viewing students as consumers, and others who are vehemently against it.

\section{Arguments For}

Overall, proponents of viewing students as consumers are arguing for a comprehensive, institution-wide customer service strategic plan, especially in eLearning. They are looking at the reality...the fact that competition from online programs is encroaching in their service areas, and online options for students are multiplying exponentially, while the reduction of state budgets are forcing educators to do more with less. Recent articles elucidate the turning point higher education is currently facing, specifically regarding the impact and role that fast-paced changes in technology and business are having on it. For example, Selingo [17] recently observed, "The disruption that technology has inflicted on the retail sector over the past decade is often used to illustrate what is about to happen in higher education" (para. 3). Similarly, Daphne Koller, a leader in eLearning noted, "there is a sense ... of urgency and realization that we are at the cusp of a huge transformation" (as cited in [14], para. 15). Rhally [14] concurs, "...with hundreds of classes offered to millions of students for free over the past few years, online education platforms have already started to disrupt the higher education world" (para. 15). Technology is also spurring fast-paced changes in business that are impacting higher education.

Henry [7] observed that the Internet, social media, and mobile devices have blurred the lines of customer service. To make the point, he provides examples of businesses, that until the dawn of Internet-only companies, had little competition, or at least, they knew how to manage it. Today, Henry pointed out [7], "companies in every industry find themselves competing with new types of competitors within and outside of their industry - cable companies with Netflix, travel agents with Expedia, and everyone is seemingly competing with Amazon, eBay, Apple and Starbucks" [7, para. 6]. He added that education is not exempt because although these companies are not competing with education, "students are using their experiences with these companies and relating them to their experiences in higher education" (para. 6). He concluded, "simply stated, our competitors are not just our peer institutions, but increasingly those who are outside our industry" (para. 6). This has opened the flood gates, paving the way for vast opportunities, as well as challenges that necessitate a change in the way higher education administrators, faculty, and staff view students and the delivery of services.

According to Mintz [10] "the most important challenge involves a shift in the way students consume higher education" (para. 5). In this sense, to the proponents of viewing students as consumers, students are indeed customers. They have choices and they make them known. With the Internet and social media, the power is in the prospective and current students' fingertips. Alternatives to their local, and other online higher education programs 
are not only a click away, but they are able to very easily find out about, as well as a report on, positive and negative experiences with their selections [7]. According to Henry [7], "this is important to note because a bad experience is no longer just telling their close family and friends. Experiences can go viral in matter of minutes on YouTube, which can significantly damage institutional brand and our services' reputation" (para. 6). This has thrust higher education into the social media arena much sooner, and with much more serious consequences, than it ever expected [11]. Higher education institutions will need to manage their social media, much in the same way large business do "to manage brand reputation and respond to customers" [11, para. 9]. This is relevant to the discussion of viewing students as consumers because today, prospective and current college students shop around for institutions, programs, and even courses, using the technology and communication tools at their fingertips. Opinions regarding their educational experiences will also depend on how quickly and effectively the institution can communicate with them during their time there. Today, news travels fast. Through word of mouth (or Facebook) students learn which courses and programs to take and which ones to avoid.

Consequently, researchers $[10,14,16,17]$ predict that higher education institutions will change or risk staying behind or even, not surviving. "If the past decade was about building climbing walls and palatial dormitories to attract students, the decade ahead for colleges will be about proving their value to prospective students and families increasingly unwilling to pay higher tuition prices" [17, para. 12]. Morris [11] added, "Emerging and converging trends in technology are additionally forcing the hand of traditional higher education institutions to innovate their service, support and communication on an almost immediate basis, a parallel shared by big brands that are reeling to adapt to the always-connected consumer" (para. 2). Part of this change, involves taking a much more business approach to higher education, looking seriously at such things as, the student as consumer, competition, return on investment, branding, customer service, and accountability. Mintz [10] observed, "...colleges must become more nimble, entrepreneurial, student-focused, and accountable for what students learn" (para. 5).

Adopting the student-as-consumer model for providing customer service can have several benefits, including increasing recruitment, maintaining enrollment, and positively impacting retention and student satisfaction, which can enhance student pass and graduation rates. A recent survey conducted by the Recruiting \& Retaining Adult Learners division of Jossey-Bass [5] revealed, "Adult learners encounter many hurdles to reach their academic goals as they juggle school with work, family and financial responsibilities. They often arrive at college with rusty academic skills and little to no knowledge about how to navigate the services they must access to complete key transactions and get the support they need" (para. 1). In the classroom, the impact of the customer service model is even more significant. "Instructors are the personnel that students most often interact with. If students have professors who don't understand their life situations or learning needs, they may lose motivation" [5, para. 10] and "ultimately drop out" [5, para. 5]. Adopting the student-as-consumer perspective campus-wide will help ensure consistency and quality in the delivery of all services.

Consequently, the business model is increasingly pervading higher education as fast-paced changes in technology are coupled with increased competition and opportunities for students. Seeing students as consumers means continually assessing their changing needs and balancing that with providing a high quality education. This brings with it its own set of challenges, leading many educators to argue against treating students as consumers.

\section{Arguments Against}

Opponents of viewing students as consumers argue that this perspective gives students a sense of entitlement that negatively impacts the educational experience. Vedder (as cited in [3]), noted that this is evidenced by the increased role of students in decision-making since the implementation of student evaluations. He said, "the growth in grade inflation, the near abandonment of Friday classes on many campuses, and the provision of country club-like facilities are three indicators that universities increasingly look at students as customers requiring pampering" [3, A Pampered Population, para. 1].

Similarly, opponents of viewing students as consumer, argue that this way of doing business blurs the boundaries between instructors and students, as well as imposes unreasonable expectations on the instructor and the institution. Hardeman [6] observed, "the trendy but toxic student-as-consumer metaphor" (para. 3) impacts the students' understanding of roles and the acceptable behaviors that accompany them, thereby thwarting the development of one of the most important skills students learn in college- communication. Examples of grade 


\section{Issues in Information Systems \\ Volume 15, Issue $x$, pp. 380-389, 2014}

inflation, hesitance to hold students back, the building of expensive recreational facilities, creating shortcuts in degrees such as transferrable work experiences and academic blocks, shortening semesters, and marketing programs into less expensive packages that are often accompanied with gifts of technology abound. Kreuter [9] credits these trends to "the customer is always right" that follows the perception of students as customers.

Opponents add that even if the customer model is adopted, it is unrealistic to expect that the consumer drives institutional decisions and practices. "Even in settings where engaged customers interact with companies to influence the value and nature of what they consume, sellers don't set demanding expectations of customers and partner with them on strategic initiatives (Snyder, as cited in [3], para. 1). They pay for a product and receive it.

In addition, this view can harm students by instilling an entitlement mentality that can prevail beyond college into the workplace. "A sense of 'customer entitlement' can cause some students to occasionally forget that a college education is actually an early glimpse of the professional world that awaits them" [6, para. 7]. The concern is that seeing the student as consumer confuses the hierarchy of roles learned in the college classroom environment, which prepares students for the workplace, where a level of respect is granted to the supervisor (in this case, the instructor) and a sense of responsibility is instilled in the employee (in this case, the student).

Opponents, like proponents, recognize the converging financial, economic, and academic circumstances that are making administrators and faculty in higher education take a long hard look at what services they provide, how they provide them, and how they obtain and maintain their stream of students. "Institutions, especially branch campuses of public university systems and small private colleges, feel perpetually strapped for cash and desperate for tuition revenue" [12, para. 3]. Compounding the issue is the skyrocketing costs of higher education, making students fearful that it will take them years to pay off their college debt [12]. "It's no wonder that American students in particular bring the cult of "the customer is always right" to the college campus. They've paid their money-or they will over the next 30 years or so-now they want service" [12, para. 5]. Conversely, with increasingly reduced financial aid, grants, and state budgets, tuition is quickly becoming the main source of revenue for many higher education institutions. It makes sense then that business terms, practices, and models have infiltrated education, because it is the customers that keep a business viable. In this case, the customers are the students [12].

However, Perry [12] warns, "but public discourse has consequences for how we think and act. Tell faculty members that they are obligated to treat students like customers, and the instructors will either eschew rigor in favor of making satisfaction guaranteed or work defensively lest they be harangued by the irate customer" (para. 5). Similarly, he added, "tell students that they are consumers, and they will act like consumers but ultimately learn less and perhaps not even receive the credential that they think they are buying" [12, para. 5].

Even staunch opponents recognize that there is a benefit to the approach of students-as-consumers, and that is, that it helps infuse and maintain accountability in education. Kreuter [9] noted, "we are and ought to be accountable to students and to taxpayers" (para. 14). However, he cautions, "but the student-as-customer model makes us accountable to the wrong values, to purely financial motives" [9, para. 14], confusing the purpose of higher education. "The trite but powerful idea that the customer is never wrong...enables us to forget what our product is. The university itself becomes the product, rather than the education that the university provides" [9, para. 11]. In summary, opponents of viewing students as consumers argue that this perspective gives students a sense of entitlement that blurs the boundaries between instructor and student, as well as imposes unreasonable expectations on the instructor and the institution, thereby negatively impacting the quality of education they receive.

\section{WHAT DO STUDENTS THINK?}

During the Spring 2014 semester, online students enrolled one master's and two doctoral Educational Technology courses were asked to describe what customer service should look like in a fully online classroom and how it could be achieved while maintaining appropriate boundaries in the student-faculty relationship. Students' comments were posted to a cross-classroom blog that addressed contemporary topics and issues related to the Educational Technology profession.

Of the 39 total student responses, a small percentage expressed a customer entitlement mentality with regard to their education. Typical responses from this small group included: 
"College institutions do need to be aware that they are in a business supported by students. The success rate of students is a reflection upon the school and the type of education it provides."

"I do not want or need a professor to be my 'friend.' I am paying for an education. I am paying for value - not a grade. I am paying for my education so I do expect some things."

"I expect respect. As long as I respect you; please respect me. I do not like 'snarky', rude comments and attitudes from my professors."

Yet, a significant majority of students recognized that, even though they had certain expectations of their professors, boundaries needed to exist between students and faculty. Most students expressed high, but realistic expectations for their instructors. For example:

"As a student, I want to make sure that my professors know who I am and will guide me to academic success. However, I also recognize that professors have lives outside of their profession. I would never expect an email response faster than 24 hours and I would never call a professor on their cell phone unless invited to."

"I always appreciate it when professors clearly spell out how they would like to be contacted and emphasize the best possible way. For example, if they prefer that I text or email them with a question."

"I like it when professors make projects and assignments so explicitly clear that I don't have to ask questions. I am a fairly self-sufficient learner and prefer to complete assignments without a lot of guidance. If instructions are vague, I feel frustrated when I have to contact my professors for help."

"Students appreciate the sense of worth when faculty see value in their learning."

"In an online classroom, first impressions do matter. I expect the course to look professional and to be easy to navigate. I also expect the syllabus and course assignments to be clearly written and self-explanatory."

"I expect faculty to be professional, knowledgeable, and respectful. I expect clear communication and appropriate responsiveness to questions and requests for assistance."

"There is a real perception of things that tells university staff that students are essentially customers paying for a service that they expect will be of quality and would make an impact in their future. On the other hand, teachers have to make sure that their actions are not driven by an over simplified 'economic transaction' kind of relationship. Both positions need to meet at some middle ground of academic understanding that a teacherstudents relationship is a basic human relationship in which there should be respect, mutual abidance to clearly delineated class rules and expectations, and, ultimately, a common desire to achieve certain goals such as the ones described in the objectives of the syllabus."

\section{ANALYSIS OF OPPOSING VIEWPOINTS}

While the debate over whether the student-as-consumer metaphor is appropriate in an instructional context will probably continue for years, there is no doubt that proponents from both sides have raised valid concerns.

On the one hand, universities are experiencing intense competition from external entities that are encroaching upon their once-safe service areas. Supporters of the student-as-consumer metaphor recognize that with the ascension of distance education into the mainstream and the massive growth of fully online programs, "students are voting with their feet" [10, para. 5] to pursue greater educational opportunities. Indeed, as Raisman [13] observes, the growth of online programs is pitting for-profit and traditional colleges and universities against each other as they compete for the same students. This competition, Raisman [13] asserts, is shifting the balance of power away from schools in favor of the students. Consequently, in order to attract and retain these students, institutions of higher education are beginning to adopt a more entrepreneurial, student-focused approach to remain competitive. 
On the other hand, opponents to the student-as-consumer debate worry that treating students like consumers will instill a sense of "customer entitlement" that "can often obstruct the behavioral boundaries in dealing with professors" [6, para. 7]. While the balance of power may shift in favor of students on the business side, Raisman [13] argues that the one area where institutional power must be upheld is in maintaining classroom decorum. According to Raisman [13], it is poor customer service, for example, to not control cell phone usage in class, let students arrive late, or permit inappropriate language, because these behaviors, if tolerated, can disrupt the entire class. Perry [12] argues, "students who believe they are mere customers are selling themselves short..." (para. 7) inasmuch as customer service implies a mere exchange of services for money. According to Perry [12], this view of customer service undermines the true value of a college education, which is the provision of a "well-structured opportunity to learn or obtain... meaningful credentials" (para. 8).

Yet, as Perry [12] explains, "when students explicitly define themselves as customers, it's often in the context of perceived bad teaching, a sense that the structure surrounding the learning opportunity is somehow deficient" (para. 8). In this context, is there value in the power of the student as consumer? Is there a way to reconcile the two opposing views while respecting the validity in the arguments of both sides? If so, what common sense customer service measures could be adopted to online instruction? Based on student input and the research literature, the following best practice recommendations have emerged.

\section{ADAPTING BEST PRACTICES OF SERVICE QUALITY TO BEST PRACTICES IN ONLINE INSTRUCTION}

While there are many frameworks for identifying or defining exceptional customer service in business and industry, one model that is particularly appropriate for online learning was proposed by Micah Solomon, author of the book, High-Tech, High Touch Customer Service. Solomon, as cited in Hernandez [8], identified four pillars of customer service. These four pillars, not surprisingly, align with many of the best practices of online instruction as described in Chickering and Gamson's Seven Principals of Good Practice [4] and California State University, Chico's Rubric for Online Instruction [15]. The following discussion describes Solomon's Four Pillars of Customer Service and how they align to best practices in online instruction.

- The Perfect Product. Solomon described the perfect product as a product or service that was designed to work perfectly.

In a distance-learning context, the online course should also work perfectly. The user-interface should be easy to understand and navigate. The content should be clearly and unambiguously written and selfexplanatory. Every section of the course should be formatted cleanly and professionally, and be free of spelling and/or grammatical errors. Assignment instructions should explicitly and methodically described, including all deliverables, due dates, submission instructions, instructor's expectations, and assessment rubrics. Complex processes should include links to just-in-time tutorials and supplemental resources in order to enable students to perform the tasks with minimal assistance. The sixth principle of Chickering and Gamson's Seven Principals of Good Practice [4] emphasizes the importance of communicating high expectations for everyone. Consequently, if faculty are to expect excellence from their students, they need to model it through their actions and the quality of their work. As was evident by one student's response to the customer service issue, "In an online classroom, first impressions do matter. I expect the course to look professional and to be easy to navigate. I also expect the syllabus and course assignments to be clearly written and self-explanatory."

- Caring Delivery. Solomon cautioned that even a great product or service will be avoided if appropriate care and attention is not exercised during the transaction.

In the words of Maya Angelou [2], “...people will forget what you said, people will forget what you did, but people will never forget how you made them feel" (para. 1). Because online students may oftentimes feel isolated from their peers and instructors, a strong instructor presence and support is essential in helping students to feel less isolated. When reflecting on (and evaluating) their learning experiences, students will remember with greater clarity how they were treated much more than what they learned. The first principle of Chickering and Gamson's Seven Principals of Good Practice [4] emphasizes the importance of frequent 
student-faculty contact. It states, "Frequent student-faculty contact in and out of class is a most important factor in student motivation and involvement" [4, p. 3]. The Rubric for Online Instruction [15] also identifies the importance of providing ample opportunities for interaction and communication student-tostudent, student-to-instructor, and student-to-content in the Instructional Design and Delivery domain. As one student reflected in his blog entry, "As a student, I want to make sure that my professors know who I am and will guide me to academic success."

- Timeliness. Solomon cautioned that a perfect product delivered late was a defective product.

In a distance-learning context, the perfect product with regard to timeliness is timely feedback to students' questions and graded assignments. Timeliness in delivering student feedback is not just a best practice, but lack of timely and actionable feedback may negatively impact students' grades, especially when successive graded assignments build upon each other. The fourth principle of Chickering and Gamson's Seven Principals of Good Practice [4] emphasizes the importance of prompt feedback in in order to let students "reflect on what they have learned, what they still need to know, and how they might assess themselves" [4, p. 4]. Similarly, the Rubric for Online Instruction [15] identifies regular and timely feedback about student performance as a key element of the Assessment and Evaluation of Student Learning domain. A common theme among students' expectations of faculty is exemplified by one student's blog entry: "I expect clear communication and appropriate responsiveness to questions and requests for assistance."

- Building an Effective Problem-Resolution Process. Instead of waiting for things to go wrong, Solomon advocates the proactive implementation of an effective problem-resolution process.

While most institutions offer IT support to assist online students with technical problems relating to email or learning management issues, they are not prepared to resolve a myriad of non-technical issues that can arise in an online course. In some instances, faculty are the only ones capable of responding to these types of issues. One effective way for faculty to implement a problem-resolution process in their online courses is to provide students with multiple avenues of communication with generous, but reasonable boundaries. The Rubric for Online Instruction [15] identifies Learner Support and Resources as one of the most important ways to provide students access to supplemental resources for supporting course content, including contact information for when students require additional assistance. As one student observed, "I always appreciate it when professors clearly spell out how they would like to be contacted and emphasize the best possible way. For example, if they prefer that I text or email them with a question.”

As illustrated in Table 1 below there is a close alignment between Solomon's common-sense approaches for delivering high quality customer service and many of the best practices for facilitating high quality distance learning as measured by California State University, Chico's Rubric for Online Instruction [15]. The Rubric for Online Instruction was designed to answer the question, "What does high quality online instruction look like?" [15, para. 1]. 
Table 1. Solomon's Four Pillars of Customer Service, as cited in Hernandez [8], compared to California State University, Chico's Rubric for Online Instruction [15], based on Chickering and Gamson's [4], Seven Principles of Good Practice in Undergraduate Education.

\begin{tabular}{|c|c|c|}
\hline & $\begin{array}{l}4 \text { Pillars of Customer Service } \\
\text { (Solomon, 2013) }\end{array}$ & $\begin{array}{l}\text { Rubric for Online Instruction } \\
\text { (California State University, 2002) }\end{array}$ \\
\hline Perfect Product & $\begin{array}{l}\text { Good practice emphasizes excellence in } \\
\text { design and delivery of services and } \\
\text { products. A perfect product is designed to } \\
\text { work perfectly all the time. }\end{array}$ & $\begin{array}{l}\text { Good practice communicates high quality and } \\
\text { expectations. A well-designed course is } \\
\text { meticulously organized, accessible, and easy } \\
\text { to navigate. All content is well written, free of } \\
\text { grammatical and spelling errors, and self- } \\
\text { explanatory. }\end{array}$ \\
\hline Caring Delivery & $\begin{array}{l}\text { Good practice promotes the delivery of } \\
\text { products and services with care and } \\
\text { attention. A perfect product or service } \\
\text { executed without care and attention is a } \\
\text { defective product }\end{array}$ & $\begin{array}{l}\text { Good practice respects diversity--talents, } \\
\text { experience, and ways of learning. A well- } \\
\text { designed course promotes learning and } \\
\text { engages students through purposefully } \\
\text { delivered innovative teaching methods and } \\
\text { interactive multiple visual, textual, kinesthetic } \\
\text { and/or auditory activities. }\end{array}$ \\
\hline Timeliness & $\begin{array}{l}\text { Good practice emphasizes timely delivery } \\
\text { of goods and services. A perfect product } \\
\text { delivered late is a defective product. }\end{array}$ & $\begin{array}{l}\text { Good practice emphasizes the delivery of } \\
\text { prompt feedback. A well-designed course } \\
\text { provides multiple opportunities for students to } \\
\text { receive regular and timely feedback about } \\
\text { their performance. }\end{array}$ \\
\hline $\begin{array}{l}\text { Effective } \\
\text { Problem- } \\
\text { Resolution }\end{array}$ & $\begin{array}{l}\text { Good practice promotes a proactive } \\
\text { approach to solving problems. Instead of } \\
\text { waiting for problems to arise, anticipate } \\
\text { them and be ready to ready to respond. }\end{array}$ & $\begin{array}{l}\text { Good practice encourages student-faculty } \\
\text { interaction and values student feedback. } \\
\text { Instructors use formal and informal student } \\
\text { feedback on an ongoing basis to identify } \\
\text { problem areas and improve instruction. }\end{array}$ \\
\hline
\end{tabular}

\section{CONCLUSIONS}

In summary, the four pillars of customer service delineated above do not contradict any of the arguments in the student-as-consumer debate. If anything, they provide a compromise that respects both points of view, while positively impacting students' and faculty's online learning experiences. While the literature in higher education is strewn with articles written by people who argue passionately for or against viewing students as consumers, maybe it is time to develop a new model. Instead of viewing the student as consumer, a more appropriate perspective may be viewing the student as a client. Consumers are usually the boss because they pay money to purchase something. For example, they go into a fast food restaurant, order, pay, and expect to get a satisfactory meal and a fast food dining experience. In education and other service-related industries, such as law and engineering, instead, the members of the target audience are referred to as clients. In this model, the professional and the client have responsibilities and a code of behavior and ethical guidelines that are expected of both.

Viewing students as clients is not about seeing them as the boss, who pay for a product and expect to receive it. It is about both sides recognizing and fulfilling their duties and responsibilities to each other. It is about providing exceptional customer service during clients' experiences from beginning to end to ensure that they enroll, stay, and graduate...as well as, spread the word to colleagues, families, and friends about their positive experiences.

What students, especially online students are looking for is the entire package. A place where they can obtain: information quickly and comprehensively while they are searching for the right course or program; the help they 


\section{Issues in Information Systems \\ Volume 15, Issue $x$, pp. 380-389, 2014}

need to enroll; a relevant and productive learning experience; and the ongoing support they need throughout the program until completion. The whole package, however, is not so easy to deliver effectively online.

Therefore, instead of a confrontational relationship between service provider and consumer, Perry [12] envisions a learning environment with shared responsibility between students and teachers:

I believe that it's possible to turn a class into a microcommunity of learners and teachers. Such an approach yields some of the power back to the students and makes us collaborators, all governed by expectations, feedback, evaluations, and conversations (para. 18).

In his closing argument, Perry challenges educators to move past the student-as-consumer discussion so we can focus on delivering the best educational experience possible for all stakeholders.

\section{REFERENCES}

1. Allen, I. E., \& Seaman, J. (2013). Changing course: Ten years of tracking online education in the United States. Retrieved February 15, 2014, from http://www.onlinelearningsurvey.com/reports/changingcourse.pdf

2. Angelou, M. (n.d.). Maya Angelou quotes. Goodreads. Retrieved April 22, 2014, from http://www.goodreads.com/quotes/5934-i-ve-learned-that-people-will-forget-what-you-said-people

3. Are They Students? Or 'Customers'? (2010, January 10). The New York Times. Retrieved March 1, 2014, from http://roomfordebate.blogs.nytimes.com/2010/01/03/are-they-students-orcustomers/? _php=true\&_type $=$ blogs\&_r $=0$

4. Chickering, A. W., \& Gamson, Z. F. (1987). Seven principles for good practice in undergraduate education. AAHE Bulletin, 3-7.

5. Gomez, C. (2013, April 13). Adults often encounter lack of understanding, caring from service units, faculty members. Jossey-Bass Recruiting \& Retaining Adult Learners. Retrieved December 27, 2013, from http://www.recruitingretainingadultlearners.com/m-article-detail/adults-often-encounter-lack-ofunderstanding-caring-from-service-units-faculty-members.aspx

6. Hardeman, K. T. (n.d.). Students and communication competence: A call to professors for establishing appropriate communication boundaries. Academic Exchange Extra. Retrieved May 7, 2014, from http://www.unco.edu/ae-extra/2010/2/hardeman.html

7. Henry, J. (2014, March 3). Our customers in higher education just happen to be students. A Better Way Forward. Retrieved March 13, 2014, from http://studentaffairsfeature.com/our-customers-in-higher-educationjust-happen-to-be-students

8. Hernandez, P. (2013, June 14). How to deliver exceptional customer service. Small Business Computing and InternetNews.com. Retrieved January 3, 2014, from http://www.smallbusinesscomputing.com/tipsforsmallbusiness/how-to-deliver-exceptional-customerservice.html

9. Kreuter, N. (2014, February 27). Customer mentality. Insider Higher Ed. Retrieved March 4, 2014, fromhttp://www.insidehighered.com/views/2014/02/27/essay-critiques-how-student-customer-idea-erodes-keyvalues-higher-education\#sthash.7BGm1M80.wsUmt6bA.dpbs

10. Mintz, S. (2013, July 22). The future is now: 15 innovations to watch for. The Chronicle of Higher Education. Retrieved April 24, 2014, from http://chronicle.com/article/The-Future-Is-Now-15/140479

11. Morris, T. (2013, October 17). 6 technology trends forming an alliance between customer service \& higher education. Business 2 Community. Retrieved March 10, 2014, from http://www.business2community.com/customer-experience/6-technology-trends-forming-alliancecustomer-service-higher-education-0651468\#!FNprt

12. Perry, D. M. (2014, March 17). Faculty members are not cashiers. The Chronicle of Higher Education. Retrieved April 3, 2014, from https://chronicle.com/article/Faculty-Members-Are-Not/145363

13. Raisman, N. (2014, May 6). Service power shifts on campus. Great Service Matters. Retrieved May 7, 2014, from http://academicmaps.blogspot.com

14. Rhally, C. (2014, February 7). Higher education gets another online challenger, as WEF launches Its own web courses. Student Reporter. Retrieved March 10, 2014, from http://studentreporter.org/2014/02/higher-educationgets-another-online-challenger-as-wef-launches-its-own-web-courses 


\section{Issues in Information Systems}

Volume 15, Issue $x$, pp. 380-389, 2014

15. Rubric for Online Instruction. (2002). California State University, Chico: CA. Retrieved May 7, 2014, from http://www.csuchico.edu/roi/

16. Savenije, D. (2013, July 24). 4 ways universities can survive extinction. EducationDIVE. Retrieved March 10, 2014, from http://www.educationdive.com/news/4-ways-universities-can-survive-extinction/148644

17. Selingo, J. (2013, December 2). Colleges can still save themselves. Here's how. The Chronicle of Higher Education. Retrieved March 20, 2014, from http://chronicle.com/article/Colleges-Can-Still-Save/143305 